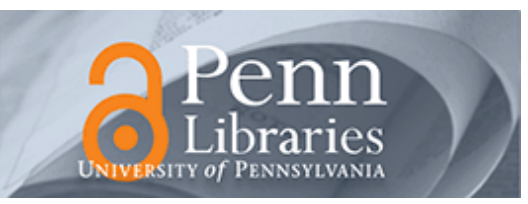

University of Pennsylvania

ScholarlyCommons

\title{
REE Zoning in Allanite Related to Changing Partition Coefficients During Crystallization: Implications for REE Behaviour in an Epidote-Bearing Tonalite
}

\author{
J S. Beard \\ S S. Sorensen \\ Reto Gieré \\ University of Pennsylvania, giere@sas.upenn.edu
}

Follow this and additional works at: https://repository.upenn.edu/ees_papers

Part of the Earth Sciences Commons, and the Environmental Sciences Commons

\section{Recommended Citation}

Beard, J. S., Sorensen, S. S., \& Gieré, R. (2006). REE Zoning in Allanite Related to Changing Partition Coefficients During Crystallization: Implications for REE Behaviour in an Epidote-Bearing Tonalite. Mineralogical Magazine, 70 (4), 419-435. http://dx.doi.org/10.1180/0026461067040337

At the time of publication, author Reto Gieré was affiliated with the Institute of Earth and Environmental Sciences Geochemistry, University of Freiburg. Currently, he is a faculty member in the Earth \& Environmental Department at the University of Pennsylvania.

This paper is posted at ScholarlyCommons. https://repository.upenn.edu/ees_papers/96

For more information, please contact repository@pobox.upenn.edu. 


\title{
REE Zoning in Allanite Related to Changing Partition Coefficients During Crystallization: Implications for REE Behaviour in an Epidote-Bearing Tonalite
}

\begin{abstract}
Allanite is present in most samples of the tonalitic Bell Island Pluton, with an average mode near 0.05 wt.\%. Allanite occurs as cores in igneous epidote-clinozoisite and exhibits characteristic and consistent zoning patterns. REE-rich cores (All40-70) grade out towards epidote-clinozoisite with REE below electron microprobe detection limits. La, Ce and Pr contents are highest in the REE-rich cores of zoned crystals. Nd and Sm contents both initially increase as total REE decreases and are highest in intermediate zones. Y contents are generally low throughout, but tend to be highest in analyses with All5-20. The zoning behaviour exhibited by the allanite, specifically the rimward increases in $\mathrm{Nd}, \mathrm{Sm}$, and $\mathrm{Y}$, cannot be accounted for by simple fractionation and are best explained by increases in allanite/melt partition coefficients ( $K d$ values) for these elements during crystallization. We propose that the variation in $K \mathrm{~d}$ values reflects modification of the allanite structure with changing $R E E$ content. These modifications are manifested by changes in colour, extinction, and pleochroism within the zoned crystals and include changes in unit-cell volume and dimensions. The changes in $K \mathrm{~d}$ values are large enough to result in crossing REE patterns within single allanite crystals. Fractional crystallization of zoned allanite can have noticeable effects on $L R E E$ contents and $\mathrm{La} / \mathrm{Sm}$ (and almost certainly La/Lu) in magmas. In the Bell Island pluton, $80 \%$ of $\mathrm{La}$, but $<3 \%$ of $Y$ is contained in allanite. Although some of the variation in the $\angle R E E$ chemistry of the pluton is attributable to statistical sampling error, much of it appears to reflect petrogenetic processes that controlled $L R E E$ abundance and, ultimately, allanite mode. One sample of Bell Island tonalite is depleted in $L R E E$ and has low $\mathrm{La} / \mathrm{Lu}$ and $\mathrm{La} / \mathrm{Sm}$. These chemical features can be modelled by fractionation of zoned allanite.
\end{abstract}

\section{Keywords}

allanite, zoning, REE, partitioning, tonalite

\section{Disciplines}

Earth Sciences | Environmental Sciences | Physical Sciences and Mathematics

\section{Comments}

At the time of publication, author Reto Gieré was affiliated with the Institute of Earth and Environmental Sciences Geochemistry, University of Freiburg. Currently, he is a faculty member in the Earth \& Environmental Department at the University of Pennsylvania. 


\title{
REE zoning in allanite related to changing partition coefficients during crystallization: implications for REE behaviour in an epidote-bearing tonalite
}

\author{
J. S. BeARD ${ }^{1, *}$, S. S. SORENSEN ${ }^{2}$ and R. GieRE ${ }^{3}$ \\ ${ }^{1}$ Virginia Museum of Natural History, 1001 Douglas Avenue, Martinsville VA 24112, USA \\ 2 Department of Mineral Sciences, Smithsonian Institution, PO Box 37012, National Museum of Natural History, \\ NHB-119, Washington DC 20013-7012, USA \\ ${ }^{3}$ Mineralogisch-Geochemisches Institut, Albert-Ludwigs-Universität, Albertstrasse 23b, D-79104 Freiburg, \\ Germany
}

\section{ABSTRACT}

Allanite is present in most samples of the tonalitic Bell Island Pluton, with an average mode near 0.05 wt.\%. Allanite occurs as cores in igneous epidote-clinozoisite and exhibits characteristic and consistent zoning patterns. REE-rich cores $\left(\mathrm{All}_{40-70}\right)$ grade out towards epidote-clinozoisite with $R E E$ below electron microprobe detection limits. $\mathrm{La}, \mathrm{Ce}$ and $\mathrm{Pr}$ contents are highest in the REE-rich cores of zoned crystals. $\mathrm{Nd}$ and $\mathrm{Sm}$ contents both initially increase as total REE decreases and are highest in intermediate zones. Y contents are generally low throughout, but tend to be highest in analyses with $\mathrm{All}_{5-20}$. The zoning behaviour exhibited by the allanite, specifically the rimward increases in $\mathrm{Nd}, \mathrm{Sm}$, and Y, cannot be accounted for by simple fractionation and are best explained by increases in allanite/ melt partition coefficients ( $K_{\mathrm{d}}$ values) for these elements during crystallization. We propose that the variation in $K_{\mathrm{d}}$ values reflects modification of the allanite structure with changing $R E E$ content. These modifications are manifested by changes in colour, extinction, and pleochroism within the zoned crystals and include changes in unit-cell volume and dimensions. The changes in $K_{\mathrm{d}}$ values are large enough to result in crossing REE patterns within single allanite crystals. Fractional crystallization of zoned allanite can have noticeable effects on $L R E E$ contents and $\mathrm{La} / \mathrm{Sm}$ (and almost certainly $\mathrm{La} / \mathrm{Lu}$ ) in magmas. In the Bell Island pluton, $80 \%$ of $\mathrm{La}$, but $<3 \%$ of $\mathrm{Y}$ is contained in allanite. Although some of the variation in the $L R E E$ chemistry of the pluton is attributable to statistical sampling error, much of it appears to reflect petrogenetic processes that controlled LREE abundance and, ultimately, allanite mode. One sample of Bell Island tonalite is depleted in LREE and has low $\mathrm{La} / \mathrm{Lu}$ and $\mathrm{La} / \mathrm{Sm}$. These chemical features can be modelled by fractionation of zoned allanite.

KEYwords: allanite, zoning, REE, partitioning, tonalite.

\section{INTRODUCTION}

Allanite ( CaREE $\left(\mathrm{Al}, \mathrm{Fe}^{3+}\right)_{2}\left(\mathrm{Mg}, \mathrm{Fe}^{2+}\right)$ $\left.\mathrm{Si}_{3} \mathrm{O}_{12}(\mathrm{OH})\right)$ is common as an accessory mineral in granitic and rhyolitic rocks. Although its modal abundance is low, allanite is a major residence site for LREE. In some rocks, as much as $50-80 \%$ of $\mathrm{Ce}$ and $\mathrm{La}$ resides in allanite. Consequently, allanite can be used to track the

*E-mail: jbeard@vmnh.net

DOI: $10.1180 / 0026461067040337$ behaviour of REE during melting, crystallization and other igneous processes (Gromet and Silver, 1983; Sawka et al., 1984; Dawes and Evans, 1991; Sorensen, 1991; Bea, 1996; Catlos et al., 2000; also see below). Magmatic epidote grains may be progressively zoned from allanite cores, to $R E E$-rich epidote and finally, to epidote rims (e.g. Dawes and Evans, 1991; Oberli et al., 2004). Such zoning is thought to reflect the depletion of LREE in the host magma caused by allanite crystallization (Chesner and Ettlinger, 1989; Romer and Siegesmund, 2003; Gieré and Sorensen, 2004). 


\section{J. S. BEARD ET AL.}

The $90 \mathrm{Ma}, 1300 \mathrm{~km}^{2}$ Bell Island Pluton (BIP) is a component of the mid-Cretaceous continental arc exposed in SE Alaska and NW British Columbia (Crawford et al., 1987; Gehrels and Berg, 1994; Rubin and Saleeby, 2000; Fig. 1). The pluton consists of coarse-grained (up to $10 \mathrm{~mm}$ ), hypidiomorphic granular epidotebiotite-hornblende tonalite with minor granodiorite and quartz diorite. The BIP is one of the original igneous epidote occurrences described by Zen and Hammarstrom (1984). Alteration of this tonalite is generally minor, manifested by nonpervasive, dusty, sericitic alteration of plagioclase and local chloritization of biotite. Contact metamorphic assemblages and the local presence of igneous garnet suggest that emplacement pressures ranged from 6 to $10 \mathrm{kbar}$ (Cook and

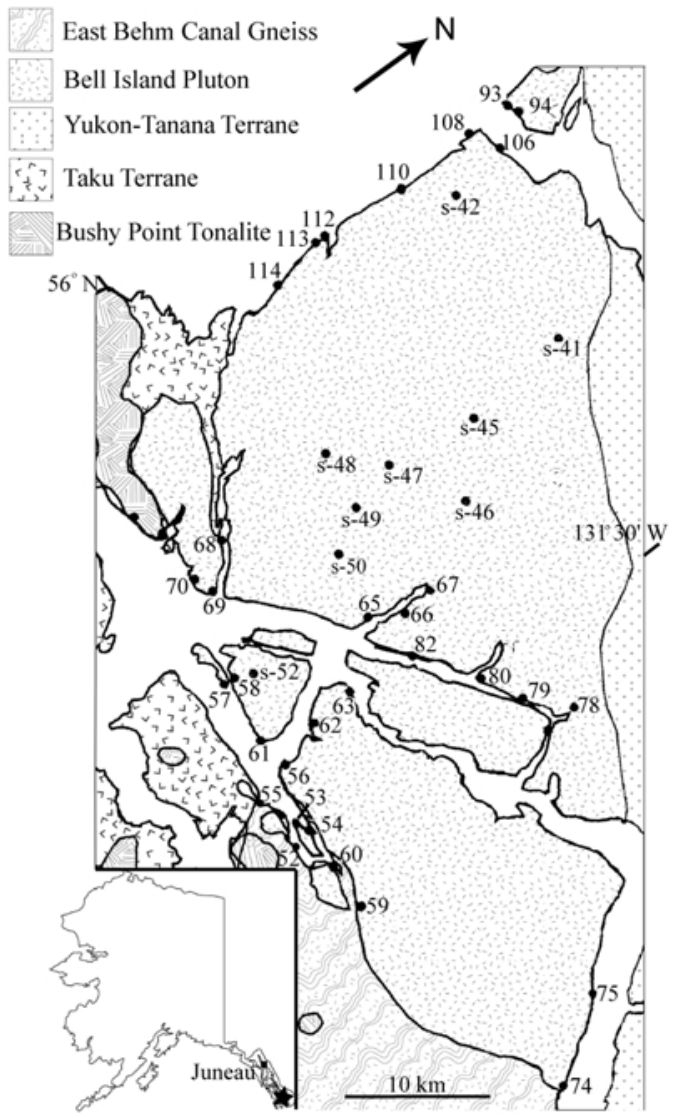

FIG. 1. Location (star) and map of the Bell Island Pluton with sample locations. Terrane and other unit designations after Gehrels and Berg (1994) and Rubin and Saleeby (2000).
Crawford, 1994), consistent with the presence of igneous epidote (Zen and Hammarstrom 1984; Schmidt and Thompson, 1996). Allanite was found in 40 of 44 BIP thin sections examined for this study. The composition of the tonalite is given in Table 1.

Our work demonstrates that the zoning behaviour in these allanites must result from changes in partition coefficients $\left(K_{\mathrm{d}}\right)$. At the outset, however, we emphasize that this study is not designed to provide $K_{\mathrm{d}}$ values for use in petrological modelling, but to describe and propose a mechanism for producing chemical zoning in natural allanites. Experiments and data from glassy volcanic rocks (see Frei et al. (2004), for a review) provide the best absolute partition coefficient numbers for purposes of petrological modelling.

\section{Petrography and chemistry}

\section{Petrography}

In the BIP, allanite occurs as pale yellowish- to reddish-brown, pleochroic, zoned euhedral to subhedral crystals. In all but a few cases, allanite is mantled by colourless, subhedral to interstitial epidote with $R E E$ below the microprobe detection limit (e.g. $<0.05$ wt.\% for $\mathrm{Ce}_{2} \mathrm{O}_{3}$; Table 1). Textural relationships (e.g. Zen and Hammarstrom, 1984; Keane and Morrison, 1997) strongly suggest that the epidote mantles are products of igneous crystallization, not of a later metamorphic overprint. Most allanite crystals are small $(<0.2 \mathrm{~mm})$, but grains with maximum dimensions $>1 \mathrm{~mm}$ do occur and account for much of the measured allanite mode. In most cases, there is an abrupt optical and compositional boundary between allanite and mantling epidote (but no obvious resorptive or other physical discontinuity). Allanite's euhedral form and its presence as inclusions in garnet, biotite and amphibole indicate that it is a relatively early-crystallizing phase.

Allanite constitutes an estimated $0.05 \%$ of the BIP by weight. This estimate was calculated by measuring the area of every allanite grain in all 40 thin sections. The total area of all allanite grains was divided by the total area of all thin sections (a total of 44 thin sections including the four in which no allanite was found). This 'areal mode' was then converted to a mass fraction using a density of $3.8 \mathrm{gm} / \mathrm{cm}^{3}$ for allanite and $2.46 \mathrm{gm} / \mathrm{cm}^{3}$ (calculated on the basis of pointcounted modes) for the host rock. There is no 
obvious pluton-scale zoning with regard to either the abundance or composition of allanite.

\section{Analytical methods}

Allanite was analysed using the Cameca SX-50 electron microprobe in the Department of Geological Sciences at Virginia Tech. Standards for $R E E$ are stoichiometric REE compounds $\left(\mathrm{LaVO}_{4}, \mathrm{CePO}_{4}, R E E_{2} \mathrm{Si}_{2} \mathrm{O}_{7}\right)$. The standard for $\mathrm{Y}$ is a synthetic yttrium garnet (YAG). Counting times were $20 \mathrm{~s}$ (peak) and $10 \mathrm{~s}$ (background). The relatively short count times are a compromise designed to allow collection of data from a large number of crystals. As in many published allanite analyses, the totals reported here for allanite are low. The lowest totals $(<93 \mathrm{wt} . \%)$ occur in allanite grains that contain $>2.5$ wt. $\% \mathrm{ThO}_{2}$. Such grains may be partially metamict, but account for fewer than $5 \%$ of the allanites analysed. Otherwise, there is a strong correlation between total REE content and analytical total. This may, in part, reflect unanalysed REE. Gd, in particular, could not be analysed due to peak interferences. We emphasize that these problems will not affect the principal conclusions of this paper which concern variations in the relative abundances of REE.

\section{Allanite chemistry}

In this text, the allanite component is defined as 100REE/12.5 oxygens (atomic). For the sake of simplicity, this report refers to all epidote-group minerals with an allanite component of $>1 \mathrm{~mol} \%$ (equivalent to $0.01 R E E$ atoms per 12.5 oxygens) as allanite rather than $R E E$-rich epidote (see Gieré and Sorensen, 2004 for a discussion of the likely compositional limits of allanite sensu stricto). $\mathrm{Y}$ is treated as a $R E E$ (and a proxy for Ho). Ferric iron is calculated by assumption of perfect stoichiometry with 8 cations per 12.5 oxygens. Mn was assumed to be $\mathrm{Mn}^{2+}$. Because $\mathrm{Mn}$ is a minor component of allanite, this assumption will not introduce large stoichiometric errors.

More than 540 individual allanite analyses (Fig. 2) from 51 allanite crystals in 38 samples (as well as an additional 95 analyses collected in detailed traverses across two grains) are reported in Appendix A which has been deposited with the Principal Editor and is available from http:// www.minersoc.org/pages/e_journals/ dep_mat.html. As is characteristic of allanite from igneous rocks (e.g. Gieré and Sorensen, 2004),
BIP allanites are enriched in LREE, and $\mathrm{Ce}$ is always the most abundant lanthanide. The analyses were collected during several programmed traverses ( $1-5$ traverses and 4-30 total spots) across one or two allanite crystals per thin section. For purposes of comparison, the data set is divided into seven compositional bins ranging from $\mathrm{All}_{1-5}$ to $\mathrm{All}_{>60}$ (Fig. 2). Binned averages (average of all spot analyses in a given compositional range) and overall sample average allanite (average minimum, average maximum, and total average for the 38 samples for which allanite was analysed) and epidote compositions are given in Table 1. The binned averages are used to infer overall trends in allanite composition within the data set. The traverses illustrate that compositional characteristics evident in the binned averages reflect typical core-rim compositional variations seen in single zoned crystals.

Overall, the allanite component ranges from 1 to $73 \%$, with an average, mode and median near $\mathrm{All}_{40}$ (Fig. 2). All allanite crystals are zoned, with an average maximum of $\mathrm{All}_{52}$ and average minimum (disregarding mantling epidote, all of which is $A l_{<1}$ ) of $\mathrm{All}_{20}$. As the allanite component decreases, the clinozoisite component increases until clz/ep $\approx 1$ (Fig. $3 a, b) . \mathrm{Mg}$ and $\mathrm{Fe}^{2+}$ increase with REE (Figs $3 c, d ; 4 a, b$ ) while $\mathrm{Ca}+\mathrm{Mn}$ decrease (Fig. $4 c$ ), reflecting the typical allanite substitution:

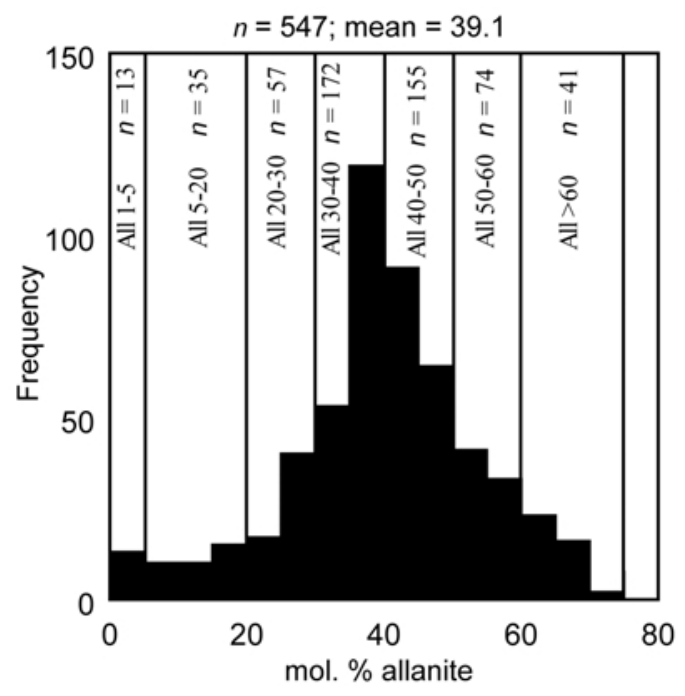

FIg. 2. Compositional distribution of all allanite analyses, Bell Island Pluton. The seven compositional bins used in Figs 3, 7 and 8 and the numbers of analyses in each bin are indicated and tabulated in Table 1. 
J. S. BEARD ET AL.

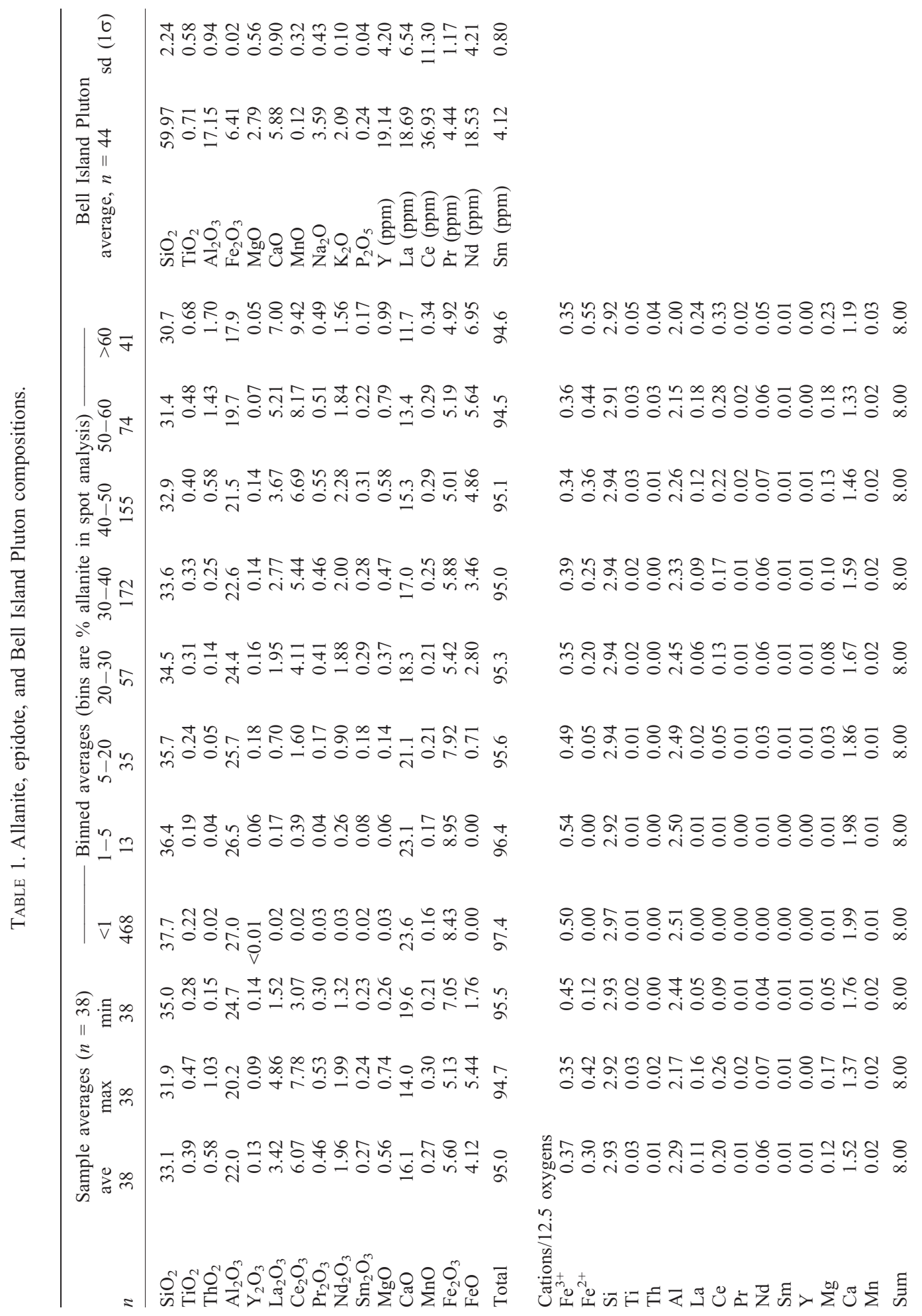




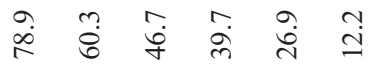

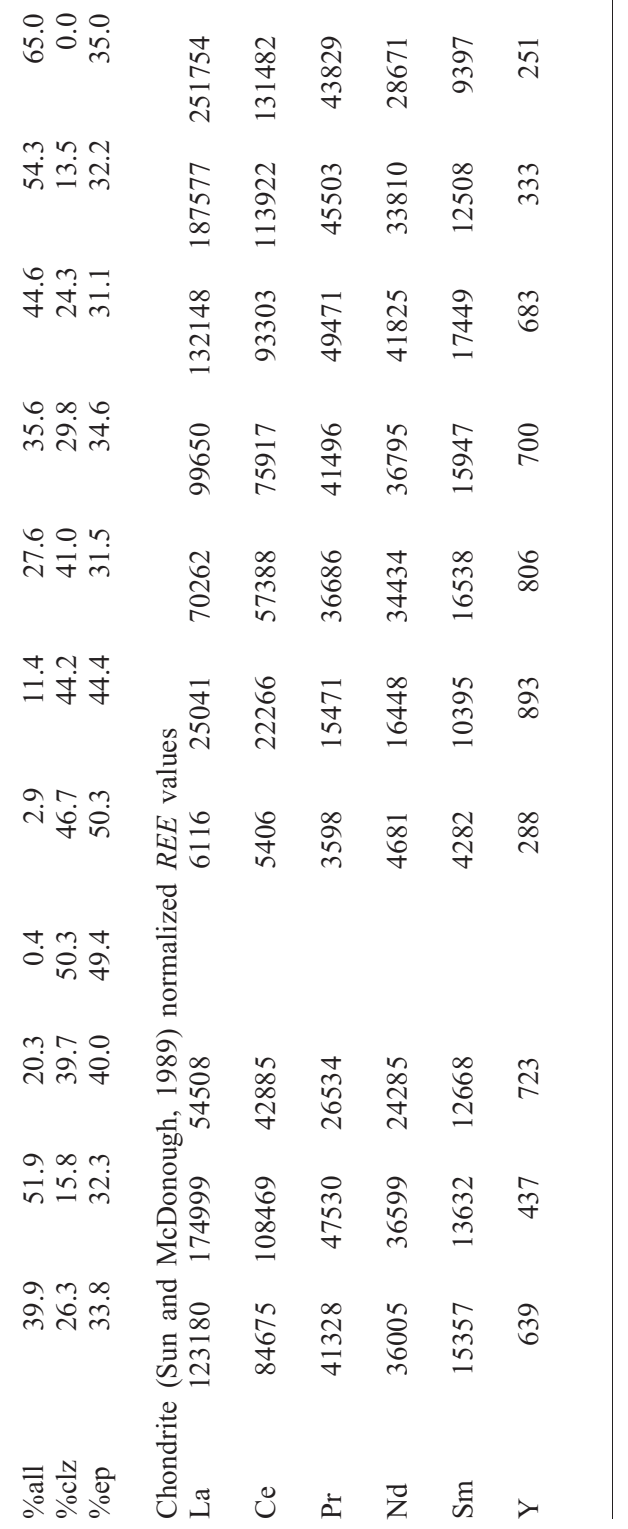

$$
R E E^{3+}+\left(\mathrm{Mg}, \mathrm{Fe}^{2+}\right)=\mathrm{Ca}+\left(\mathrm{Al}, \mathrm{Fe}^{3+}\right)
$$

allanite (dissakisite) clinozoisite, epidote

The most REE-rich analyses have a ferriallanite component (i.e. $\mathrm{Fe}^{3+}>1$ per 12.5 oxygens; Fig. $3 a, b$ ). High $\mathrm{Fe}^{2+}$ in one sample (s-41) may reflect incorporation of $\mathrm{Fe}^{2+}$ into the $\mathrm{Ca}$ site (Fig. 4b,c; Catlos et al., 2000). Th is enriched in $R E E$-rich allanite. Anomalously high Th is found in two samples (in circled field on Fig. 4d). One of these is s-41. This relationship between high $\mathrm{Th}$, low $\mathrm{Ca}$ and 'excess' $\mathrm{Fe}^{2+}$ suggests a substitution such as:

$$
\mathrm{Th}^{4+}+2 \mathrm{Fe}^{2+}=\mathrm{Ca}^{2+}+2 \mathrm{Fe}^{3+} \text { (Gieré et al., 1999). }
$$

The trends of individual REE vs. total REE vary as a function of atomic number (Fig. $4 e-h$ ). With decreasing total $R E E$ content, (i.e. from core to rim), La decreases with a concave-up trend. Ce decreases, but nearly linearly. Neodymium initially increases as total REE decrease and is concave down. Y shows an irregular, but definite, increase to REE contents as low as 0.1 cations/ 12.5 oxygen (i.e. $10 \%$ allanite component). The relationship among these trends is also evident on a La-Nd-Y plot (Fig. 3e,f).

\section{Zoning}

The REE enrichment seen in the cores of the BIP allanites is the 'normal' zoning pattern seen in most igneous allanites (Gieré and Sorensen, 2004). The rimward decrease in total $R E E$ is probably a result of melt depletion in $R E E$ and LREE fractionation related to the crystallization of the allanite itself (Gromet and Silver, 1983; Chesner and Ettlinger, 1989; Oberli et al., 2004; Gieré and Sorensen, 2004).

Electron microprobe traverses and element maps reveal that the REE zoning in the allanite does not reflect a monotonic decrease in all REE. Although $\mathrm{La}$ and $\mathrm{Ce}$ are enriched in the cores of zoned crystals and decrease in abundance outwards, $\mathrm{Nd}, \mathrm{Sm}$ and $\mathrm{Y}$ are most abundant in the relatively $R E E$-poor outer portions of the zoned crystals (Figs 5, 6).

The REE zoning behaviour evident in single crystals is reflected by the allanite analytical data set as a whole, as summarized by averages of binned analyses. Like most allanites, the BIP allanites show a strong preference for $L R E E$ (Fig. 7a). However, as the total REE content of the allanite decreases, reflected by sharp decreases in $\mathrm{La}$ and $\mathrm{Ce}$, the contents of $\mathrm{Nd}, \mathrm{Sm}$ and $\mathrm{Y}$ (a 


\section{a}

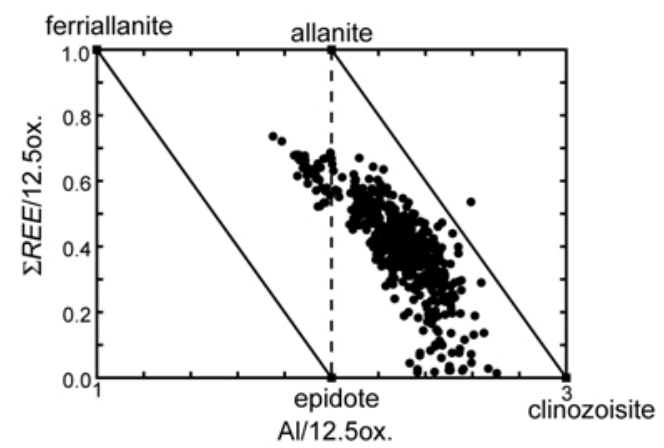

c $\quad\left(\mathrm{Al}+\mathrm{Fe}^{3+}\right)-1$

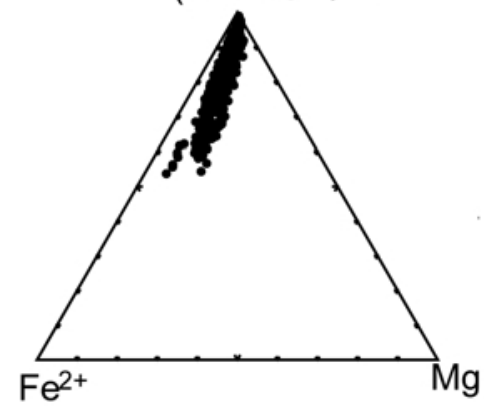

e

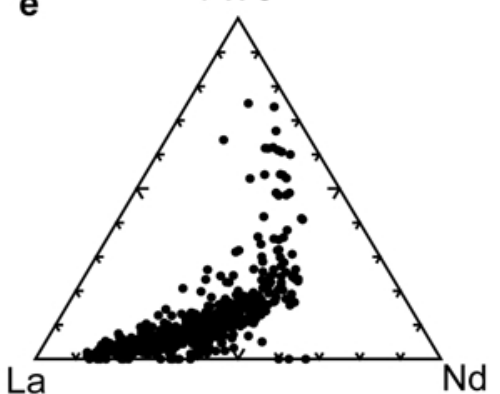

b

\section{Binned averages}
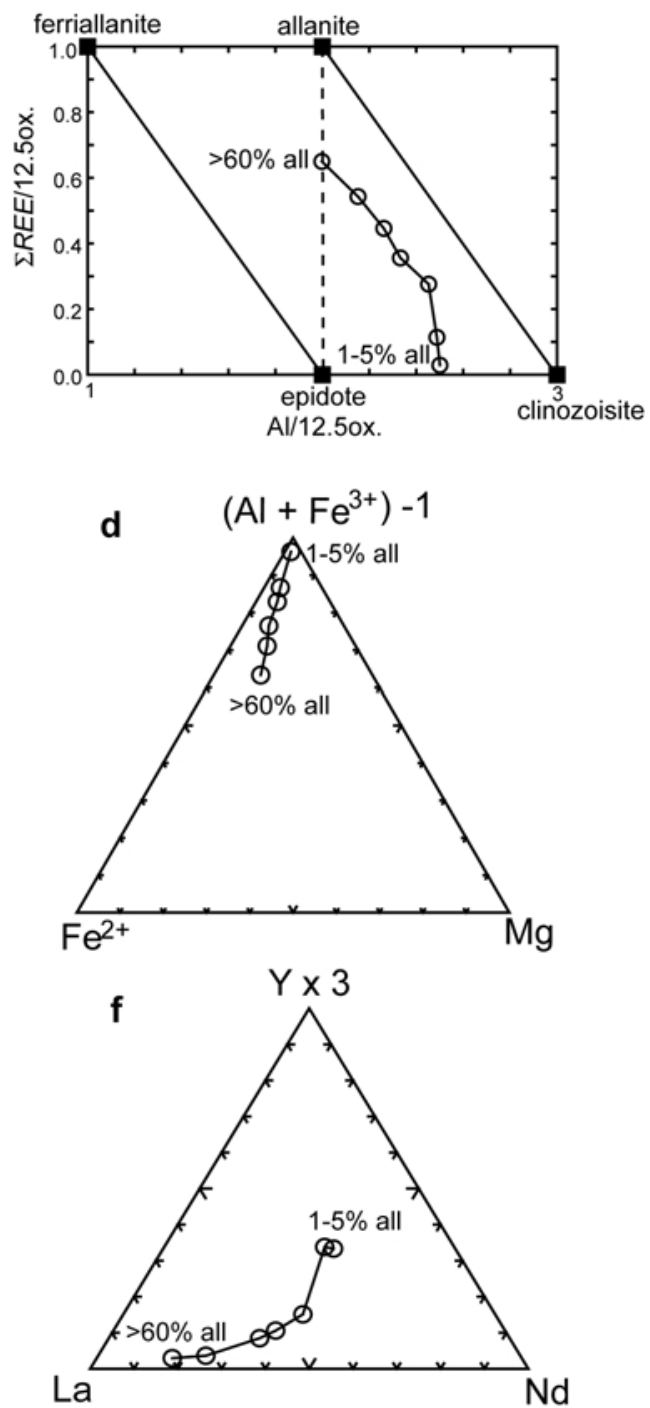

FIG. 3. Individual $(a, c, e)$ and binned average $(b, d, f)$ allanite analyses. Seven bins are defined on the basis of mole \% allanite: $1-5 \%, 5-20 \%, 20-30 \%, 30-40 \%, 40-50 \%, 50-60 \%,>60 \%$ (Table 1). (a,b) Compositions in terms of allanite, epidote, clinozoisite and ferriallanite components. (c,d) Divalent and trivalent cations exclusive of REE. $(e, f)$ Variation in La, Nd and Y.

proxy for Ho in Fig. 7a) increase. Consequently, chondrite-normalized $R E E$ patterns for the binned analyses cross (Fig. 7a).

The behaviour of all REE can be seen graphically by normalizing $R E E$ in each bin to the binned average having the highest total REE (i.e. allanite $_{>60}$; Fig. $7 b$ ). La and $\mathrm{Ce}$ are highest in the $\mathrm{All}_{>60}$ bin. On the other hand, Nd, Sm and Y contents are highest in bins having intermediate content of total REE ( $\mathrm{Sm}$ and $\mathrm{Nd}$ in the $\mathrm{All}_{40-50}$ bin; $\mathrm{Y}$ in the $\mathrm{All}_{5-20}$ bin). Maximum enrichments (i.e. $\left.R E E_{\mathrm{bin}} / R E E_{\mathrm{All}>60}\right)$ range from $\sim 1.5$ for $\mathrm{Nd}$ to $>3$ for Y (Fig. $7 b$ ). For all bins (except, of course, $\left.\mathrm{All}_{>60}\right), R E E_{\mathrm{bin}} / R E E_{\mathrm{All}>60}$ increases as a strict 

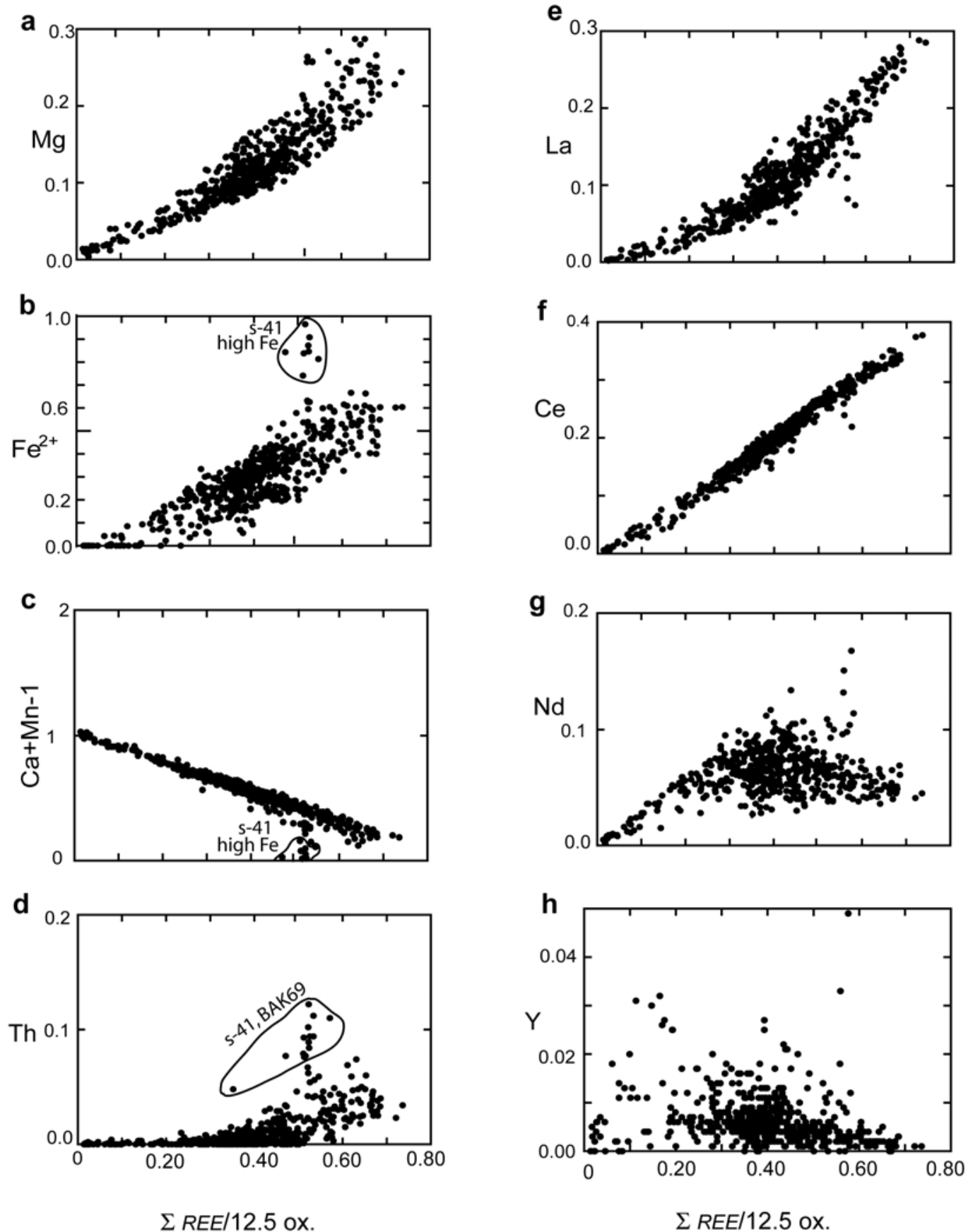

FIG. 4. Elemental variation as a function of total REE. Excess $\mathrm{Fe}^{2+}$ coupled with minor depletion in Ca+Mn in most allanite-rich samples probably reflects an $\mathrm{Fe}^{2+}>\mathrm{Ca}$ substitution. This is especially true for sample S-41. Note atomic number variation in $R E E$ behaviour. See text. 


\section{J. S. BEARD ET AL.}

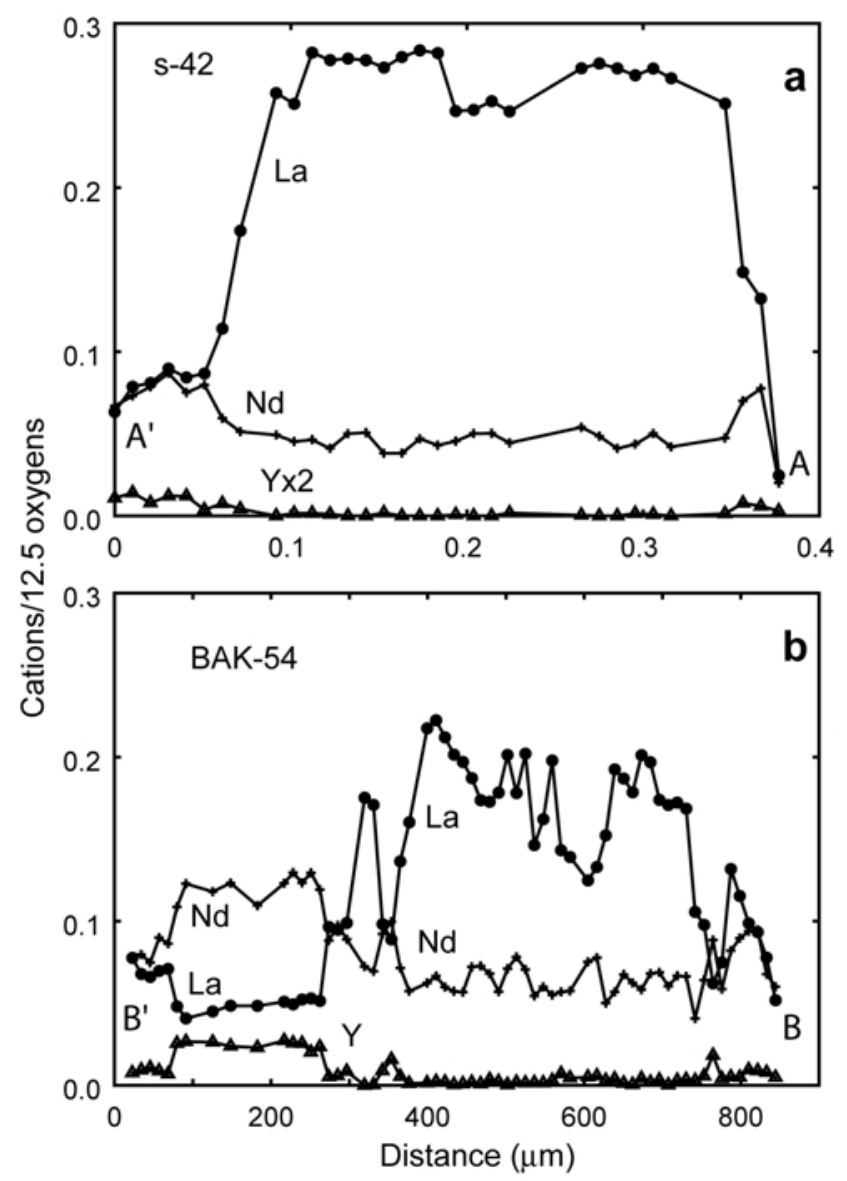

FIG. 5. Variation in REE and $\mathrm{Y}$ across zoned allanite crystals. (a) S-42, length of traverse $=0.38 \mathrm{~mm}$. (b) Bak54, length of traverse $=0.8 \mathrm{~mm}$. Both traverses are rim-to-rim. Traverse paths shown on Fig. $6 c\left(\mathrm{~S}-42, \mathrm{~A}-\mathrm{A}^{\prime}\right)$ and $6 g\left(\mathrm{BAK}-54, \mathrm{~B}-\mathrm{B}^{\prime}\right)$.

function of atomic number (with $\mathrm{Y}$ a proxy for Ho; e.g. $\mathrm{Y}>\mathrm{Sm}>\mathrm{Nd}>\mathrm{Pr}>\mathrm{Ce}>$ La) (Fig. $7 b$ ). Regardless of this, Ce is the most abundant REE in all binned averages. $\mathrm{Nd}$ is more abundant than La in the $\mathrm{All}_{<5}$ and $\mathrm{All}_{5-20}$ bins (Fig. 7c). Th is highest in the most REE-rich allanite and decreases with total $R E E$ content even more precipitously than La (Fig. $7 d$ ).

\section{Discussion: origin of REE distributions in zoned allanite}

Rimward increases of $\mathrm{Nd}, \mathrm{Sm}$ and $\mathrm{Y}$ contents in zoned allanite that produce crossing chondritenormalized REE patterns have been reported from several suites of igneous allanite (Sawka et al., 1984; Chesner and Ettlinger, 1989; Catlos et al., 2000; Buda and Nagy, 1995). This peculiar

FIG. 6 (facing page). False-colour element concentration maps, of select BIP allanites $(a-d$, S-42; $e-h$, BAK54). $(a, e)$ Ca maps. Note depletion in allanite core and high-Ca, symplectic epidote rims. External, very high-Ca (yellow) phase is apatite. $(b, f)$ Y maps. Note concentration in allanite rim. In $b$, apatite has a high Y content, but in $f$ apatite has no detectable Y. Note that zircon inclusions in $f$, however, contain substantial Y. $(c, g)$ La maps. La is concentrated in the allanite core. $(d, h) \mathrm{Nd}$ maps. $\mathrm{Nd}$ is concentrated in the rim and intermediate regions. Note that there is no discernible REE or Y signature in epidote from either sample. The traverse paths for Fig. 5 are shown on

$$
c \text { and } g \text {. }
$$


REE ZONING IN ALLANITE

\section{S-42 allanite}

a

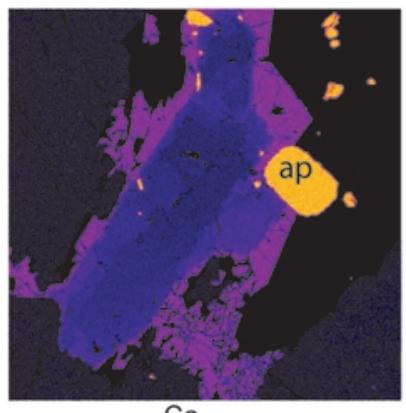

b

Ca
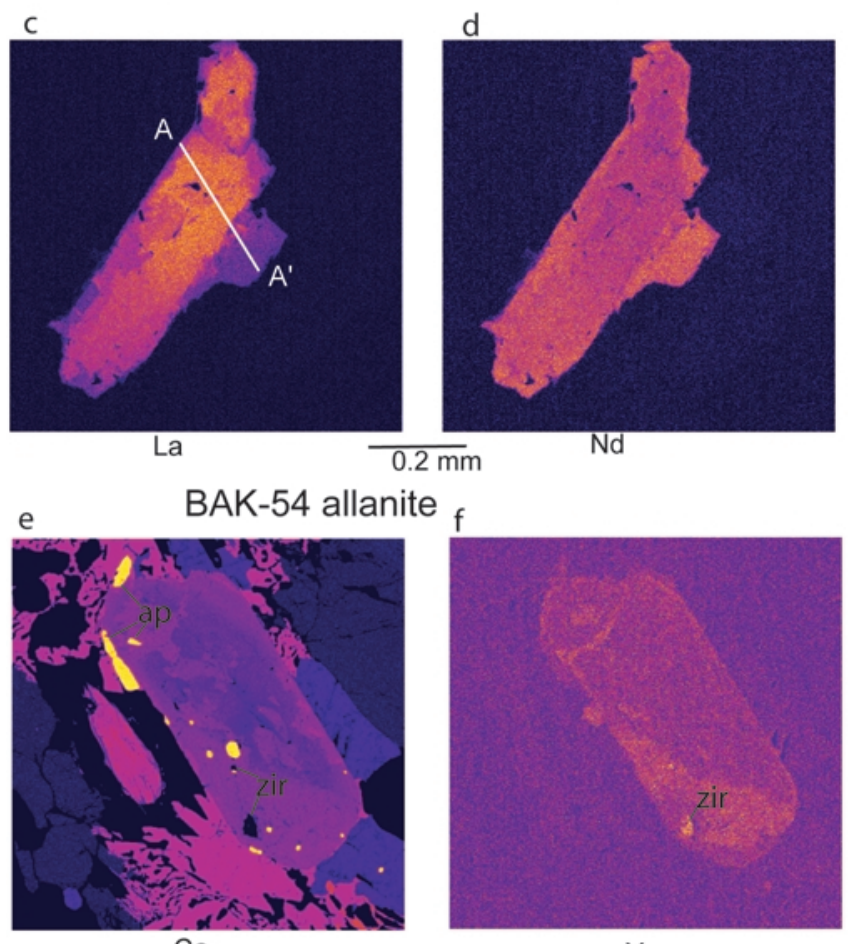

g

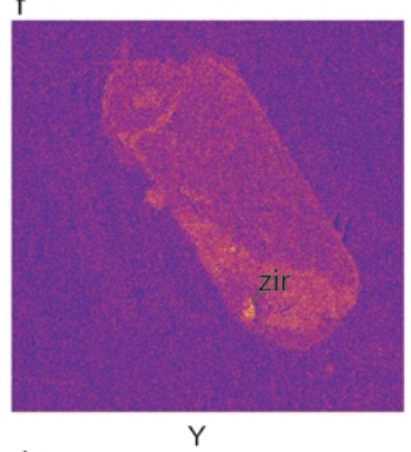

h

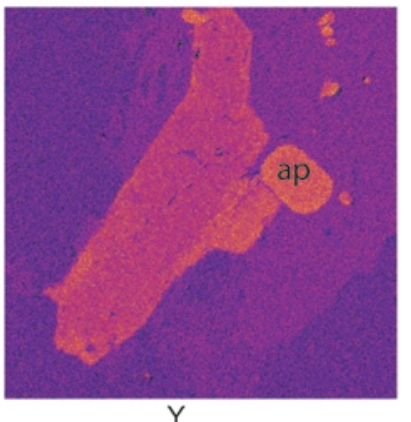

d 

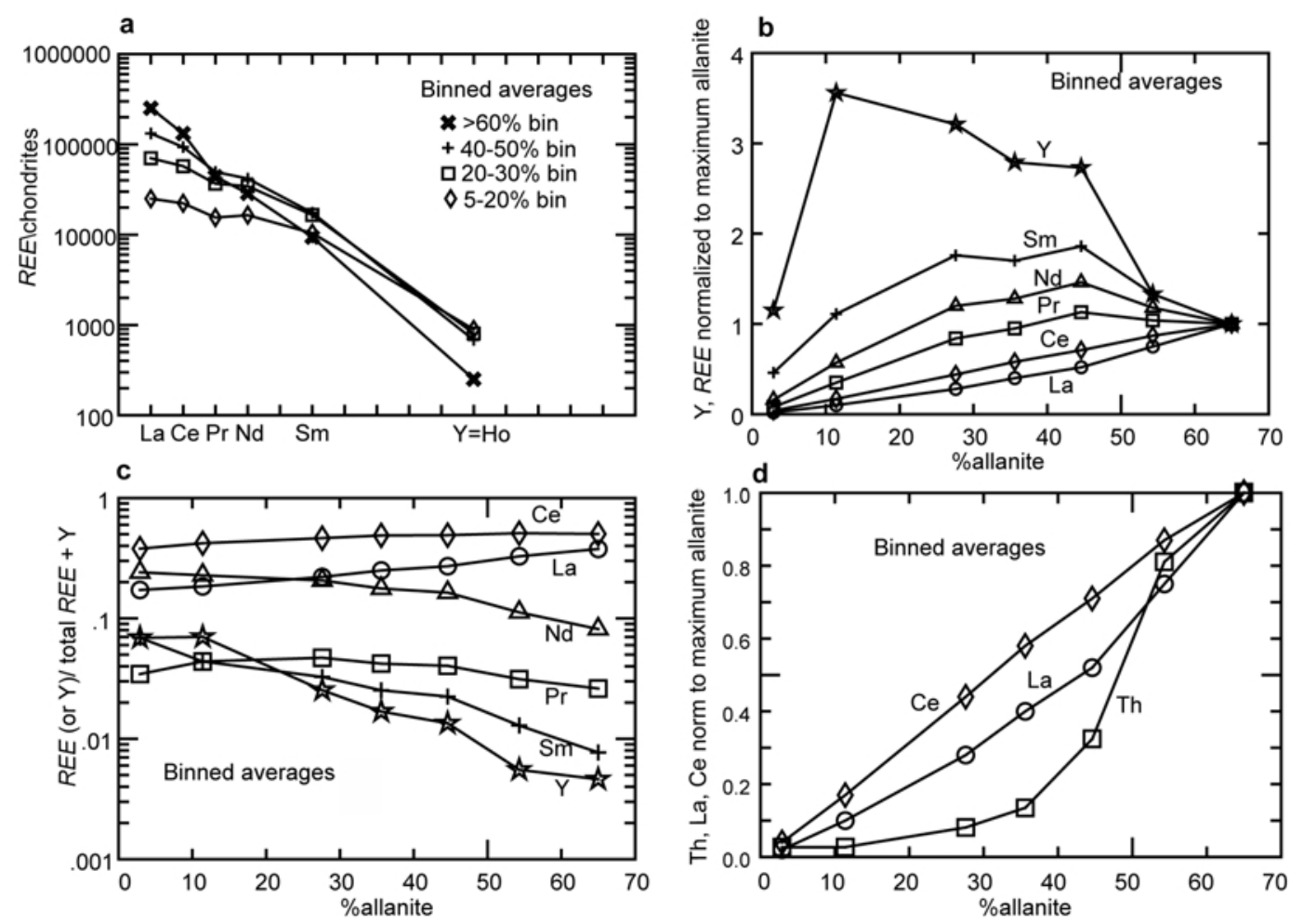

FIG. 7. REE and Y behaviour in binned allanite analyses (Table 1) as a function of mole \% allanite. (a) Chondritenormalized (Sun and McDonough, 1989) REE for selected bins. Note crossing patterns. Y is taken here and throughout as a proxy for Ho. (b) $R E E$ normalized to $R E E$ content in highest $R E E$ (allanite $>60$ ) bin. $R E E_{\text {bin }} / R E E_{\max }$ increases systematically as atomic number increases. (c) Element as a fraction of total REE. HREE increase and $L R E E$ decrease as the mole \% of allanite decreases.

characteristic of allanite zoning is commonly reported as a decrease in $\mathrm{La} / \mathrm{Nd}$ and attributed to modification of this ratio during fractional crystallization (e.g. Sawka et al., 1984). However, because partition coefficients ( $K_{\mathrm{d}}$ values) for all REE and $\mathrm{Y}$ in allanite are $\gg 1$ (Mahood and Hildreth, 1983; Ewart and Griffin, 1994; Hermann, 2002; Frei et al., 2004), fractional crystallization cannot explain the absolute increase of $\mathrm{Nd}, \mathrm{Sm}$ and $\mathrm{Y}$ seen in BIP or other igneous zoned allanites.

There are three potential explanations for the absolute increases of $\mathrm{Nd}, \mathrm{Sm}$ and $\mathrm{Y}$ in zoned allanite from the BIP. The first is that these elements are increasing in concentration in the melt during allanite crystallization. This requires open-system behaviour with large additions of $\mathrm{Nd}, \mathrm{Sm}$ and Y (but not $\mathrm{La}$ or $\mathrm{Ce}$ ) during allanite crystallization. The open system input would not only have to compensate for the removal of these elements by allanite, but to actually increase their abundance at the allanite crystallization front by a factor of 2-3. Given that rimward increases in $\mathrm{Nd}$, for example, have been documented in zoned allanites from several locations in addition to the BIP (e.g. Sawka et al., 1984; Chesner and Ettlinger, 1989), the open-system argument requires highly unusual circumstances and essentially amounts to special pleading.

The second potential explanation stems from the fact that diffusively controlled depletion in $R E E$ around a growing crystal will be inversely proportional to its allanite/melt $K_{\mathrm{d}}$, which could lead, for example, to increasing $\mathrm{Nd} / \mathrm{La}$ in zoned allanite. However, it is the absolute concentration of $\mathrm{Nd}$ (and not just $\mathrm{Nd} / \mathrm{La}$ ) that increases during crystallization of zoned allanite grains. Because $K_{\mathrm{d}}$ values for all $R E E$ in allanite are $\gg 1$ (Frei et al., 2004), this process cannot yield an absolute increase in any $R E E$. 
The third and, in our opinion, most reasonable explanation is that the allanite/melt $K_{\mathrm{d}}$ values for $R E E$ s can and do change during the crystallization of zoned allanite. Such changes in $K_{\mathrm{d}}$ values, which we model below, probably reflect subtle modifications of the crystal structure of allanite as zoned crystals grow. Zoning in allanite produces numerous optical manifestations. These include changes of colour, pleochroism and extinction, which obviously reflect at least small crystallographic changes during the growth of zoned allanite crystals. The shape and size of the allanite unit cell vary as a function of total $R E E$ content (Bonazzi and Menchetti, 1995). The unit-cell volume decreases by $\sim 1.5 \%$ as the REE content of the allanite decreases from 1 to 0.5 cations/12.5 oxygens. Furthermore, $K_{\mathrm{d}}$ vlaues for $R E E$ vary substantially within the epidote family of minerals. For example, although allanite shows a strong preference for La, zoisite preferentially incorporates Nd (Frei et al., 2003).

\section{Calculation of apparent allanite/melt $K_{d}$ values for $R E E$ and $Y$}

As with any pluton, it is difficult to assign a degree of crystallization to the BIP. Furthermore, the absolute values of allanite/melt REE $K_{\mathrm{d}}$ values for the BIP cannot be determined without knowing the total degree of crystallization of the system at the onset of allanite crystallization. However, the relative changes in $K_{\mathrm{d}}$ values for $\mathrm{Y}$ and $R E E$ during the crystallization of allanite can be tracked. We use the following procedure to calculate and track changes in allanite/melt $K_{\mathrm{d}}$ for REE and $\mathrm{Y}$ :

(1) The allanite analyses are assigned to bins (see Figs 2, 3). The mode for each bin is calculated by multiplying the overall allanite mode $(0.05$ wt. $\%)$ by the fraction of total allanite analyses represented by each individual bin. For example, $7.5 \%$ of all allanite analyses are $>\mathrm{All}_{60}$, so the mode of the $>\mathrm{All}_{60}$ bin is $7.5 \% \times 0.05 \mathrm{wt} . \%$ $=0.00375 \mathrm{wt} . \%$.

(2) Bulk mineral/rock $K_{\mathrm{d}}$ values for $R E E$ exclusive of allanite are estimated by subtracting the $R E E$ sequestered in allanite from the total $R E E$ in the BIP (Table 1).

$$
R E E_{\text {total }}-R E E_{\text {allanite }}=R E E \times{ }^{\prime} 1 .
$$

The ratio of this number to total REE in the system yields an average bulk distribution coefficient for $R E E$ and $\mathrm{Y}$ in the BIP prior to allanite crystallization: $R E E \times{ }^{\prime} 1 / R E E_{\text {total }}=$ average estimated bulk partition coefficient (bulk $K_{\mathrm{d}}$ ).

The calculated bulk $K_{\mathrm{d}}$ values are given in Table 2. Because late crystallizing trace phases such as apatite, titanite and zircon will incorporate much of the REE that are not incorporated into allanite, the estimated bulk $K_{\mathrm{d}}$ is close the maximum value for the BIP system, particularly in models (e.g. Fig. $8 d$ ) in which allanite crystallizes early. For comparison, Fig. $8 e$ shows a model in which the bulk $K_{\mathrm{d}}$ is assumed to be zero (i.e. a minimum). The models in Fig. 8 vary only slightly over the entire range of possible bulk $K_{\mathrm{d}}$ values for the BIP.

TABLE 2. REE contents of melts used to calculate apparent allanite/melt $K_{\mathrm{d}}$ values.

\begin{tabular}{lcccccc}
\hline & \multicolumn{5}{c}{$R E E$ content $(\mathrm{ppm})$} & \multicolumn{5}{c}{ at onset of allanite crystallization } \\
$\mathrm{f}$ (melt remaining) & na & 10 & 30 & 50 & 100 & 50 \\
& Bulk $K_{\mathrm{d}}$ values & & & & & \\
\hline $\mathrm{Y}$ & 0.97 & 20.4 & 19.8 & 19.5 & 19.1 & 38.3 \\
$\mathrm{La}$ & 0.28 & 99.2 & 44.7 & 30.9 & 18.7 & 37.4 \\
$\mathrm{Ce}$ & 0.34 & 170.7 & 82.2 & 58.6 & 36.9 & 73.9 \\
$\mathrm{Pr}$ & 0.58 & 11.8 & 7.4 & 6.0 & 4.4 & 8.9 \\
$\mathrm{Nd}$ & 0.56 & 50.9 & 31.4 & 25.1 & 18.5 & 37.1 \\
$\mathrm{Sm}$ & 0.72 & 7.9 & 5.8 & 5.0 & 4.1 & 8.2 \\
Key to figure & Figs $8 a-d, 8 f$ & Fig. $8 a$ & Fig. $8 b$ & Fig. $8 c$ & Fig. $8 d$ & Fig. $8 e$ \\
& & & & & & \\
\hline
\end{tabular}

For Figures $8 a$ - $d$ and $f$, melt compositions are calculated using the bulk $K_{\mathrm{d}}$ values in column 1 . For Fig. $8 e$, the melt composition is calculated assuming that bulk $K_{\mathrm{d}}=0$.

The melt composition for Fig. $8 f$ varies continuously between the compositions for $\mathrm{f}=50 \%$ and $\mathrm{f}=30 \%$ liquid remaining. 
a
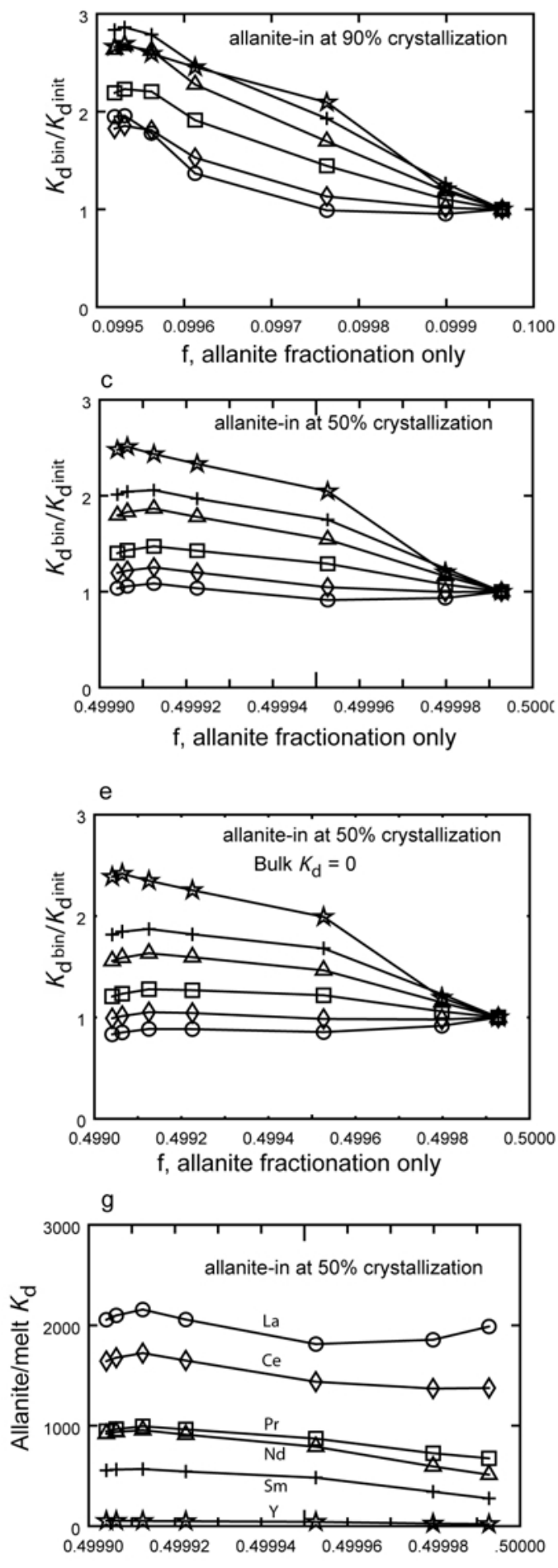

$\mathrm{f}$, allanite fractionation only b

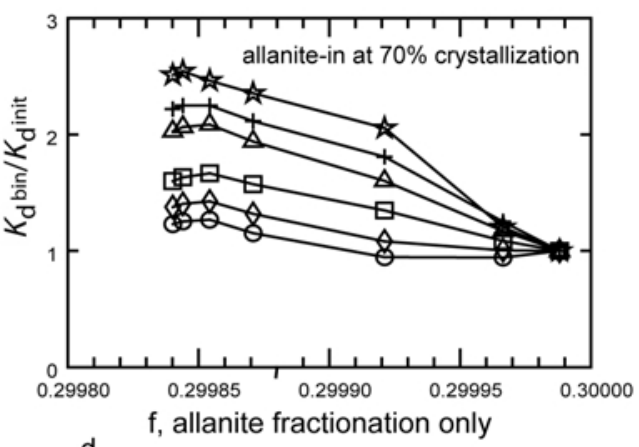

d
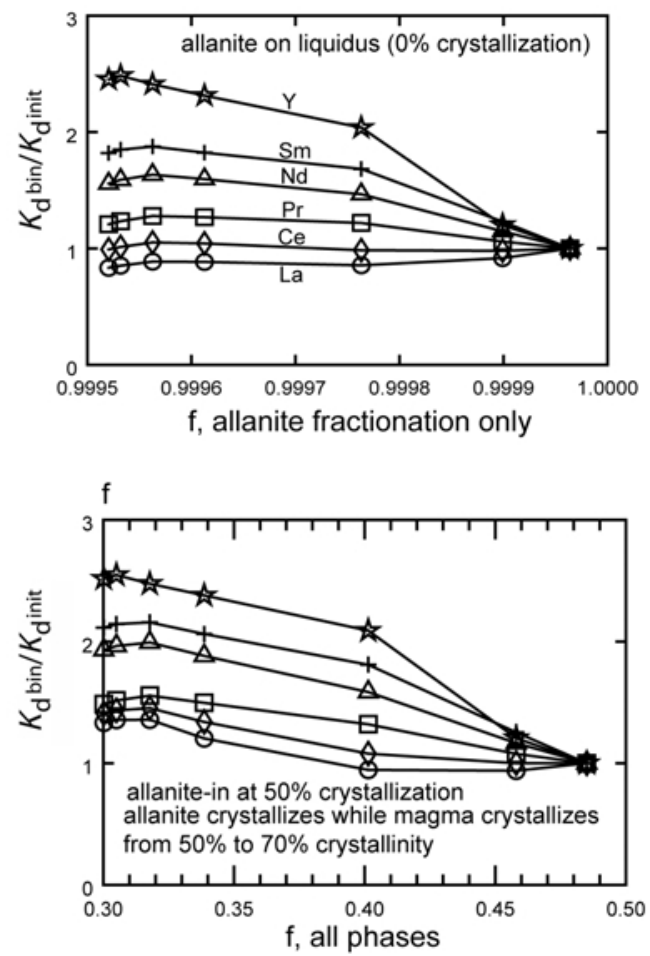
(3) The calculated bulk $K_{\mathrm{d}}$ values are used to calculate melt compositions (and, hence, apparent allanite/melt $K_{\mathrm{d}}$ values) at the onset of allanite crystallization (Table 2) for a range (10-100\%) of melt fractions remaining (f) in a putative BIP magma.

(4) The initial apparent allanite/melt partition coefficient $\left(K_{\mathrm{d} \text { init }}\right)$ is calculated using the composition of early crystallizing ( $>\mathrm{All}_{60}$ bin) allanite and the initial REE content in the modelled melt.

(5) $K_{\mathrm{d}}$ values for each subsequent bin are calculated using the melt values for $R E E$ modified by removal of all $R E E$ now sequestered in the previously crystallized allanite. For example, $R E E$ for the $\mathrm{All}_{30-40}$ bin are ratioed with the melt REE minus the REE sequestered in the $>\mathrm{All}_{60}$, the $\mathrm{All}_{50-60}$, and the $\mathrm{All}_{40-50}$ bins.

$$
\begin{gathered}
K_{\mathrm{d} 30-40}=R E E_{30-40} /\left(R E E_{\text {melt }}-R E E_{>60}-\right. \\
\left.R E E_{50-60}-R E E_{40-50}\right)
\end{gathered}
$$

(6) In Fig. $8 a-f$, the value of the $R E E /$ melt $K_{\mathrm{d}}$ for each individual bin $\left(K_{\mathrm{dbin}}\right)$ is normalized to the apparent initial partition coefficient $\left(K_{\mathrm{d} \text { init }}\right) . K_{\mathrm{d} \text { bin }} /$ $K_{\mathrm{d} \text { init }}$ is plotted to show the relative change in apparent $K_{\mathrm{d}}$ values in the compositional zoning acquired during allanite crystallization. The apparent $K_{\mathrm{d}}$ values themselves are plotted in Fig. $8 g$.

(7) In Fig. $8 a-e$, variation in f reflects only allanite crystallization and is hence very small (i.e. $<<1 \%$ ). For example, in Fig. $8 a$, allanite crystallization begins at $\mathrm{f}=0.1000$ and is completed at 0.0995. Calculating the effects of allowing allanite to crystallize over a larger crystallization interval (e.g. $\mathrm{f}=50-30$; Fig. $8 f$ ) requires adjustment of the melt composition for any additional crystallization prior to calculating the $K_{\mathrm{d}}$ for a given bin.

For the models shown in Fig. 8, the following ranges in apparent $K_{\mathrm{d}}$ were calculated: La,
440-3400; Ce, 330-2400; Pr, 200-1220, Nd, 150-1200; Sm, 100-660; Y, 11-54. These values lie within the range of published allanite/melt $K_{\mathrm{d}}$ values (Rollinson, 1993; Nielsen, 2006), although values for $\mathrm{Y}$ are significantly below those reported by Hermann (100-200 in Hermann, 2002, but also see Gieré and Sorensen (2004), p. 478). For La and Ce, $>90 \%$ of the observed range in apparent $K_{\mathrm{d}}$ values reported here can be attributed to variations in the degree of crystallization of the magma at the onset of allanite crystallization. For example, the calculated allanite/melt $K_{\mathrm{d}}$ for La at the onset of allanite crystallization is 3400 if allanite is on the liquidus but 460 if allanite crystallization begins after $90 \%$ of the magma is crystallized. For Sm and $\mathrm{Y}, 55-85 \%$ of the range reflects actual variation in $K_{\mathrm{d}}$ values during allanite crystallization. The apparent allanite/melt $K_{\mathrm{d}}$ for $\mathrm{Y}$ varies from 22 (allanite on liquidus) to 17 (late crystallizing allanite) depending on the fraction of magma crystallized at the onset of allanite crystallization. However, the apparent $K_{\mathrm{d}}$ increases from $\sim 20$ to $\sim 50$ during the course of allanite crystallization regardless of initial degree of crystallization of the magma.

\section{Trends in apparent REE Kd values}

$\mathrm{Nd}, \mathrm{Sm}$ and $\mathrm{Y}$ all show marked increases in apparent allanite/melt $K_{\mathrm{d}}$ values during crystallization. In contrast, lighter $R E E$ show little or no increase. The relative amounts of increase of apparent $K_{\mathrm{d}}$ values vary with atomic number (e.g. $\mathrm{Y}>\mathrm{Sm}>\mathrm{Nd}>\mathrm{Pr}>\mathrm{Ce}>\mathrm{La}$, with $\mathrm{Y}$ taken as a proxy for Ho); (Fig. $8 a-f$ ). For every model, the absolute value of the apparent allanite/melt $K_{\mathrm{d}}$ is greatest for the lightest REE (Fig. 8g).

The critical message in Fig. 8 is that these observations hold regardless of choice of bulk $K_{\mathrm{d}}$

Fig. 8 (facing page). Changes in calculated (apparent) allanite/melt partition coefficient $\left(K_{\mathrm{d}}\right)$ as a function of fractionation. The changes are shown as ratios of the partition coefficient calculated for each interval of crystallization $\left(K_{\mathrm{d} \text { bin }}\right)$ normalized to the partition coefficient calculated at the onset of allanite crystallization $\left(K_{\mathrm{d} \text { init }}\right)$ The horizontal axis for all plots (f) shows the liquid remaining and reflects total weight fraction crystallized from the beginning to the end of allanite crystallization. $(a-e)$ Relative change in $K_{\mathrm{d} \text { bin }} / K_{\mathrm{d} \text { init }}$ during allanite crystallization only, i.e. assuming that only allanite crystallizes during the interval in question. Apparent $K_{\mathrm{d}}$ values for heavier $R E E$ and $\mathrm{Y}$ increase substantially more than those for lighter elements. This holds regardless of the point when allanite is assumed to join the crystallization sequence of the BIP (e.g. from 0 to $90 \%$ fraction crystallized). ( $a-d$ ) Bulk partition coefficient (bulk $K_{\mathrm{d}}$ ) (exclusive of allanite) for $R E E$ is calculated from BIP mass-balance (see Table 2 and text). Part $e$ is the same as part $c$ except that the bulk $K_{\mathrm{d}}$ (exclusive of allanite) is assumed to be 0 (i.e. a minimum). (f) $K_{\mathrm{d} \text { bin }} / K_{\mathrm{d} \text { init }}$ during allanite crystallization when simultaneous crystallization of the magma is allowed, in this case from $50 \%$ to $30 \%$ liquid remaining. Relative changes are similar to those observed during crystallization of allanite alone. $(g)$ Calculated apparent $K_{\mathrm{d}}$ values. These are a function of atomic number; highest for the lightest $R E E$, lowest for Y (i.e. proxy for Ho). 


\section{J. S. BEARD ET AL.}

for REE ( 0 to maximum allowed), crystallization history $(0-90 \%$ of the system crystallized at onset of allanite crystallization), or whether or not allanite crystallizes by itself over a short $(<<1 \%)$ or with other phases during a long (20\%) interval of crystallization (Fig. 8). These are equilibrium crystallization models. Actual $K_{\mathrm{d}}$ values, assuming depletion of REE in the vicinity of crystallizing allanite, will show larger increases.

It has been proposed (Frei et al., 2003) that the overall relative fractionation of light, middle and heavy $R E E$ in allanite does not vary significantly and, hence, the substitution mechanism for incorporation of $R E E$ in allanite is also invariant. The BIP data indicate that relative fractionations of $R E E$ in allanite vary significantly in zoned crystals, which implies that the assumption of an invariant mechanism for $R E E$ substitution in allanite may need to be re-evaluated.

\section{Other trace phase repositories for REE in the Bell Island Pluton}

Although neither xenotime nor monazite has been found in the Bell Island Pluton, three other trace phases - zircon, apatite, and titanite - are present and may constitute significant repositories for $\mathrm{Y}$ and $R E E$ in the pluton. Apatite is imaged in Fig. $6 a-d$. It is evident from the image that apatite contains significant $\mathrm{Y}$ (at or above the maximum content in allanite; Fig. $6 b$ ). The image also shows that contents of both $\mathrm{La}$ and $\mathrm{Nd}$ in apatite are considerably less than the minimum contents of $\mathrm{La}_{2} \mathrm{O}_{3}$ (1.25 wt.\%) and $\mathrm{Nd}_{2} \mathrm{O}_{3}$ (1.33 wt.\%) in allanite from this sample (Appendix A; Fig. 6c,d).

Apatite and zircon are imaged in Fig. $6 e-h$. Zircon contains more $\mathrm{Y}$ than allanite and may be surrounded by $\mathrm{Y}$ depletion haloes in the allanite grains that host zircon crystals. Apatite also contains $\mathrm{Y}$, although less than either zircon or the most Y-rich regions of the allanite in Fig. $6 f$. It is evident from the images that both zircon and apatite contain substantially less than the minimum contents of $\mathrm{La}_{2} \mathrm{O}_{3}(0.8$ wt.\%) and $\mathrm{Nd}_{2} \mathrm{O}_{3}$ (0.7 wt.\%) found in allanite from this sample (Appendix a; Fig. $6 g, h$ ).

Titanite has been analysed for $\mathrm{Y}$ and $\mathrm{Nd}$ in 20 samples from the Bell Island pluton. The $\mathrm{Y}_{2} \mathrm{O}_{3}$ content averages 0.11 wt. $\%$, and $\mathrm{Nd}_{2} \mathrm{O}_{3}$ averages 0.08 wt.\%. Other REE, Ce in particular, were consistently below detection limits $(0.05$ wt.\%). Maximum zircon (0.025 wt.\%) and apatite (0.52 wt.\%) modes can be estimated from the contents of $\mathrm{P}$ and $\mathrm{Zr}$ in the Bell Island Pluton. Assuming that apatite contains $2000 \mathrm{ppm} \mathrm{Y} \mathrm{on}$ average (i.e. the maximum in the allanite grain imaged in Fig. $6 a-d), \sim 50 \%$ of $\mathrm{Y}$ in the BIP resides in apatite. If a typical zircon contains as much as 1 wt.\% Y, zircon would still only host $\sim 10 \%$ of BIP Y. Most of the rest of the Y in the pluton, along with a substantial portion $30 \%$ or so) of $\mathrm{Nd}$, probably resides in titanite.

These observations indicate that our conclusions regarding allanite/melt $R E E$ partitioning are in no way obviated by the presence of $\mathrm{Y}$ and $R E E$ in other trace phases. In fact, this evidence that other phases preferentially incorporate $\mathrm{Y}$ and $\mathrm{Nd}$ and exclude $\mathrm{Ce}$ and La strengthens the argument that the $K_{\mathrm{d}}$ values for $\mathrm{Y}$ and $\mathrm{Nd}$ in allanite must increase during the course of allanite crystallization.

\section{Allanite and REE variability in the BIP}

By mass-balance, $\sim 80 \%$ of the $\mathrm{La}$ and $70 \%$ of the $\mathrm{Ce}$, but $<3 \%$ of the $\mathrm{Y}$ in the BIP resides in allanite. Simple modal models can reproduce $L R E E$ variability in the pluton, with $L R E E$-enriched samples having twice the average allanite mode

Table 3. REE concentration data (ppm) from Bell Island Pluton used in models (Figs 9 and 11).

\begin{tabular}{lcccrrrr}
\hline BIP & $\begin{array}{c}\text { BIP } \\
\text { average } \\
(n=44)\end{array}$ & $\begin{array}{c}\text { La }<16 \text { ppm } \\
(n=15)\end{array}$ & $\begin{array}{c}\text { Ba }>25 \text { ppm } \\
(n=7)\end{array}$ & & BAK 74 & ave allanite & BAK 82 allanite \\
\hline $\mathrm{Y}$ & 19.14 & 19.86 & 19.33 & 25.00 & 23.00 & 1003 & 2205 \\
$\mathrm{La}$ & 18.69 & 12.84 & 30.90 & 21.60 & 6.90 & 29194 & 12620 \\
$\mathrm{Ce}$ & 36.93 & 27.61 & 58.58 & 41.70 & 19.10 & 51821 & 33810 \\
$\mathrm{Pr}$ & 4.44 & 3.62 & 6.67 & 4.95 & 3.12 & 3926 & 3503 \\
$\mathrm{Nd}$ & 18.53 & 15.99 & 25.98 & 20.40 & 15.90 & 16814 & 20575 \\
$\mathrm{Sm}$ & 4.12 & 3.87 & 5.12 & 4.60 & 4.60 & 2350 & 3163 \\
& & & & & & & \\
\hline
\end{tabular}


and LREE-poor samples having one-half the average allanite mode (Table 3; Fig. 9). These models have no significant effect on $\mathrm{Y}$ content and, by analogy, will probably have little effect on contents of HREE in the pluton. Variance in REE contents in the BIP is a strong function of atomic number (Fig. 10). The lightest REE show the largest relative variance $(\mathrm{La}=35 \%, \mathrm{Ce}=30 \%$, etc.). Relative variance then decreases to $\sim 20 \%$ for REE heavier than Sm (Fig. 10).

On the basis of mode and grain size (the estimated average volume of individual allanite grains in the BIP is $0.15 \mathrm{~mm}^{3}$ ), there should be $\sim 2000$ grains of allanite in a typical BIP sample $\left(\sim 1000 \mathrm{~cm}^{3}\right)$. Counting statistics alone suggest that some of the excess deviation in LREE may simply reflect variation in allanite mode due to sampling error (one standard deviation = $2000 \pm \sqrt{ } 2000=\sim 2.2 \%$ relative). However, about half of the $L R E E$ are contained in the largest $10 \%$ of allanite grains (i.e. those having a volume of $\sim 1 \mathrm{~mm}^{3}$ ). A typical sample will contain $\sim 200$ of these large crystals, and the counting error associated with their distribution will be $\sim 7 \%$ $(200 \pm \sqrt{ } 200)$. This yields a total relative error $(1 \sigma)$ attributable to counting statistics alone of $\sim 4.6 \%$ $((7 \%+2.2 \%) / 2)$. Overall, $\sim 30-60 \%$ of the excess variability in LREE (compared to HREE) can be attributed to sampling errors in the allanite mode.

Most whole-rock (i.e. ICPMS) analytical errors can be expected to affect all $R E E$ about equally (see Fig. 10). The LREE variability in the BIP as a whole can be attributed, in part, to petrogenetic

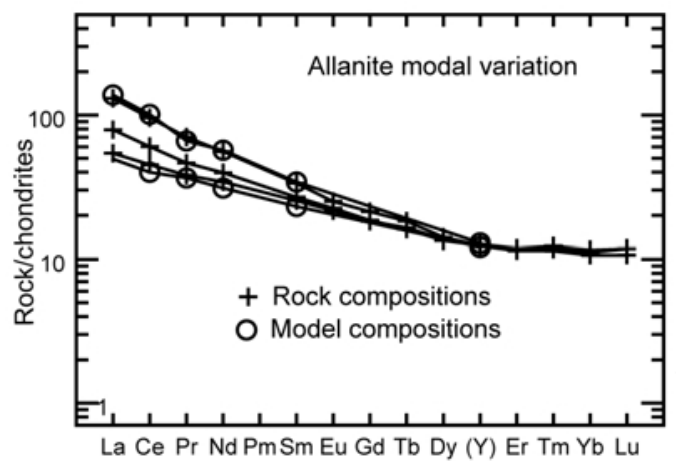

Fig. 9. (a) Average, high and low LREE BIP tonalites (crosses; Table 3) compared with simple modal models for allanite (circles). The high LREE model assumes $2 \times$ the average BIP allanite mode. The low-LREE model assumes $1 / 2$ the average BIP allanite mode. Y is plotted as a proxy for Ho. The average allanite composition used in the model is given in Table 3. processes (e.g. accumulation and/or fractionation of allanite).

The effect of fractionation of zoned allanite is evident in one BIP tonalite sample. Sample BAK82 is depleted in LREE, has the lowest whole-rock $\mathrm{La} / \mathrm{Lu}$ and $\mathrm{La} / \mathrm{Sm}$ and contains allanite having the lowest average REE content of any BIP sample. The composition of allanite from BAK 82 is similar to the $\mathrm{All}_{20-30}$ bin, both in terms of total $R E E$ and chondrite-normalized $R E E$ pattern. It is depleted in $\mathrm{La}$ and $\mathrm{Ce}$ and enriched in $\mathrm{Nd}, \mathrm{Sm}$ and $\mathrm{Y}$ with to respect to the average allanite in the BIP (Table 3; Fig. 11a). For purposes of REE modelling, BAK 74 (which has HREE like BAK82, but LREE similar to most other BIP tonalites) was chosen as a putative parent for BAK82. The whole-rock REE in BAK 82 were modelled by removal of $0.033 \%$ of REE-rich $\left(\mathrm{All}_{55}\right)$ allanite from BAK74 (Table 3; Fig. 11b). Both the allanite and bulk REE composition of BAK82 are consistent with fractionation of allanite during the development of allanite zoning.

\section{Conclusions}

(1) The absolute Nd, Sm and Y contents in zoned allanite grains from the Bell Island Pluton all increase as total REE decreases. Similar zoning effects are observed in four other igneous systems (Sawka et al., 1984; Chesner and Ettlinger, 1989; Catlos et al., 2000; Buda and Nagy, 1995). These observations make it highly unlikely that any open- or closed-system magmatic process (e.g.

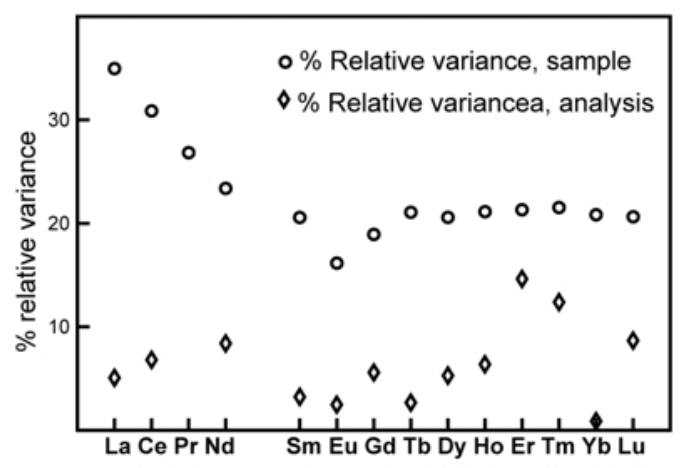

FIG. 10. Relative \% variance in $R E E$ content and relative analytical error in $R E E$ analyses from BIP whole-rock analyses. Relative variance decreases regularly from $>35 \%$ at $\mathrm{La}$ to $23 \%$ at $\mathrm{Sm}$. Except for Eu, the other REE have a relative variance $(1 \sigma)$ of $20-22 \%$. 
a

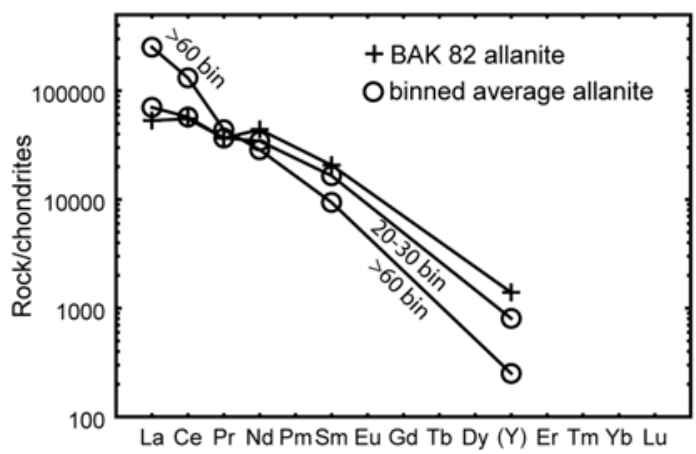

b

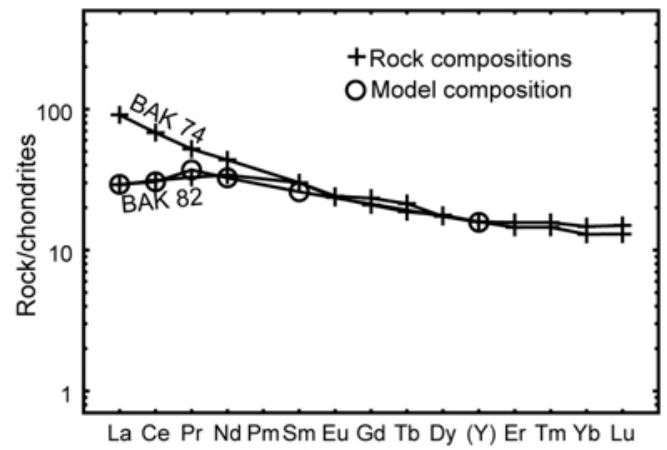

FIG. 11. Bulk and allanite REE chemistry of sample BAK82. (a) BAK82 allanite chemistry. BAK82 contains the least $R E E$-rich allanite of any sample collected from the BIP. It is very similar in composition to the $\mathrm{All}_{20-30}$ bin (Tables 1 and 3). (b) Modelled relationship between sample BAK82 and BAK74 (Table 3). Subtraction of 0.033\% of $\mathrm{All}_{55}$ allanite from BAK74 produces REE chemistry similar to that seen in BAK82.

fractionation, magma mixing, assimilation) produced the zoning. Instead, the zoning is best explained by increases of allanite/melt $K_{\mathrm{d}}$ values for $\mathrm{Nd}, \mathrm{Sm}$ and $\mathrm{Y}$ during the course of allanite crystallization.

(2) Changes of allanite composition are known to affect allanite crystallography and REE partitioning (Bonazzi and Menchetti, 1995; Frei et al., 2003). Optical properties (colour, extinction, pleochroism, etc.) vary with composition in zoned allanites and reflect crystallographic changes. These crystallographic changes are the likely agents for change of the $K_{\mathrm{d}}$ values.

(3) Within the BIP, variations of whole-rock $R E E$, particularly the $L R E E$, are linked to variations of allanite mode. Although some of the latter is attributable to counting statistics, substantial excess variation reflects the distribution of allanite. Either redistribution of allanite took place after it crystallized (most unlikely, in our opinion), or allanite compositions mirror a pre-existing variability of $R E E$ abundance in the host magma. In one sample, fractionation of zoned allanite during allanite crystallization can explain a significant depletion in $\mathrm{La}$ and $\mathrm{Ce}$ relative to $\mathrm{Nd}, \mathrm{Sm}$ and $\mathrm{Y}$.

\section{Acknowledgements}

Thanks to Craig Chesner, Fernando Bea and John Hanchar for constructive reviews which led to improvements of the manuscript. This work was supported by NSF Grant EAR0000719 to Beard and by the Virginia Museum of Natural History and the National Museum of Natural History, Smithsonian Institution.

\section{References}

Bea, F. (1996) Residence of REE, Y, Th and $\mathrm{U}$ in granites and crustal protoliths; implications for the chemistry of crustal melts. Journal of Petrology, 37, 521-552.

Bonazzi, P. and Menchetti, S. (1995) Monoclinic members of the epidote group: Effects of the $\mathrm{Al}=$ $\mathrm{Fe}^{3+}=\mathrm{Fe}^{2+}$ substitution and of the entry of $R E E^{3}$. Mineralogy and Petrology, 53, 133-153.

Buda, G. and Nagy, G. (1995) Some REE-bearing accessory minerals in two rock types of Variscan granitoids, Hungary. Geologica Carpathica, 46, 67-78.

Catlos, E.J., Sorensen, S.S. and Harrison, T.M. (2000) $\mathrm{Th}-\mathrm{Pb}$ ion-microprobe dating of allanite. American Mineralogist, 85, 633-648.

Chesner, C.A. and Ettlinger, A.D. (1989) Composition of volcanic allanite from the Toba Tuffs, Sumatra, Indonesia. American Mineralogist, 74, 750-758.

Cook, R.D. and Crawford, M.L. (1994) Exhumation and tilting of the western metamorphic belt of the Coast orogen in southern southeastern Alaska. Tectonics, 13, 528-537.

Crawford, M.L., Hollister, L.S. and Woodsworth, D.J. (1987) Crustal deformation and regional metamorphism across a terrane boundary, Coast Plutonic Complex, British Columbia. Tectonics, 6, 343-361.

Dawes, R.L. and Evans, B.W. (1991) Mineralogy and geothermobarometry of magmatic epidote-bearing dikes, Front Range, Colorado. Geological Society of America Bulletin, 103, 1017-1031. 
Ewart, A. and Griffin, W.L. (1994) Application of proton-microprobe data to trace-element partitioning in volcanic rocks. Chemical Geology, 117, 251-284.

Frei, D., Liebscher, A., Wittenberg, A. and Shaw, C.S.J. (2003) Crystal chemical controls on rare earth element partitioning between epidote-group minerals and melts: an experimental and theoretical study. Contributions to Mineralogy and Petrology, 146, 192-204.

Frei, D., Liebscher, A., Franz, G. and Dulski, P. (2004) Trace element geochemistry of epidote minerals. Pp. 553-606 in: Epidotes (A. Liebscher and G. Franz, editors). Reviews in Mineralogy and Geochemistry, 56, Mineralogical Society of America, Washington, D.C.

Gehrels, G.E. and Berg, H.C. (1994) Geology of southeastern Alaska. Pp. 451-467 in: The Geology of Alaska (G. Plafker and H.C. Berg, editors). Geological Society of America, Boulder Colorado.

Gieré, R. and Sorensen, S.S. (2004) Allanite and other REE-rich epidote-group minerals. Pp. 431-493 in: Epidotes (A. Liebscher and G. Franz, editors. Reviews in Mineralogy and Geochemistry 56, Mineralogical Society of America, Washington, D.C.

Gieré, R., Virgo, D. and Popp, R.K. (1999) Oxidation state of iron and incorporation of REE in igneous allanite. Journal of Conference Abstracts, 4, 721.

Gromet, L.P. and Silver, L.T. (1983) Rare earth element distributions among minerals in a granodiorite and their petrogenetic implications. Geochimica et Cosmochimica Acta, 47, 925-939.

Hermann, J. (2002) Allanite: thorium and light rare earth element carrier in subducted crust. Chemical Geology, 192, 289-306.

Keane, S.D. and Morrison, J. (1997) Distinguishing magmatic from subsolidus epidote: laser probe oxygen isotope compositions. Contributions to Mineralogy and Petrology, 126, 265-274.

Mahood, G.A. and Hildreth, E.W. (1983) Large partition coefficients for trace elements in high-silica rhyolites. Geochimica et Cosmochimica Acta. 47, 11-30.

Nielsen, R.L. (2006) Partition coefficient database. On line at http://earthref.org/GERM/

Oberli, F., Meier, M., Berger, A., Rosenberg, C. and Gieré, R. (2004) U-Th-Pb and ${ }^{230} \mathrm{Th} /{ }^{238} \mathrm{U}$ disequili- brium isotope systematics: Precise accessory mineral chronology and melt evolution tracing in the Alpine Bergell intrusion. Geochimica et Cosmochimica Acta, 68, 2543-2560.

Rollinson, H.R. (1993) Using Geochemical Data: Evaluation, Presentation, Interpretation. Longman, Essex, UK, $352 \mathrm{pp}$.

Romer, R.L. and Siegesmund, S. (2003) Why allanite may swindle about its true age. Contributions to Mineralogy and Petrology, 146, 297-307.

Rubin, C.M. and Saleeby, J.B. (2000) U-Pb geochronology of mid-Cretaceous and Tertiary plutons along the western edge of the Coast Mountains, Revillagigedo Island and Portland Peninsula, southeast Alaska. Pp. 145-157 in: Tectonics of the Coast Mountains, Southeastern Alaska and British Columbia (H.H. Stowell and W.C. McClelland, editors). Geological Society of America Special Paper 343, Boulder, Colorado.

Sawka, W.N., Chappell, B.W. and Norrish, K. (1984) Light-rare-earth-element zoning in sphene and allanite during granitoid fractionation. Geology, 12, 131-134.

Schmidt, M.W. and Thompson, A.B. (1996) Epidote in calc-alkaline magmas: An experimental study of stability, phase relationships, and the role of epidote in magmatic evolution. American Mineralogist, 81, 462-474.

Sorensen, S.S. (1991) Petrogenetic significance of zoned allanite in garnet amphibolites from a paleosubduction zone: Catalina Schist, southern California. American Mineralogist, 76, 589-601.

Sun, S.-s. and McDonough, W.F. (1989) Chemical and isotopic systematics of oceanic basalts: implications for mantle compositions and processes. Pp. 313-345 in: Magmatism in the Ocean Basins (A.D. Saunders and M.J. Norry, editors). Special Publication 42, Geological Society, London.

Zen, E.-An. and Hammarstrom, J.M. (1984) Magmatic epidote and its petrologic significance. Geology, 12, 515-518.

[Manuscript received 4 April 2006:

revised 1 September 2006] 
